\title{
الدافع للإنـجاز لدى الأبناء
}

\author{
إعراد \\ الباحثة/ نـجرى أحمد على معيقل
}

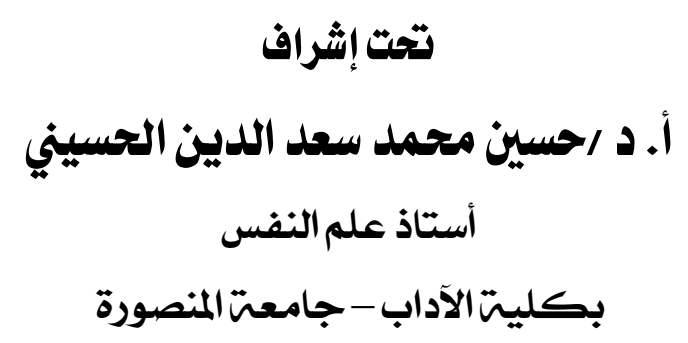

المجلت العلميت لكليت رياض الأطفال - جامعت المنصورة

المجلد الرابع ـ العدد الأول

يوليو V|r. 


\section{الدافع للإنــاز لدى الأبناء}

* نجوى أحمد على معيقل

وتعتبر الدو افع إحدى فروع علم النفس الرئيسية وفي وقتنا الحاضــر ، إذ

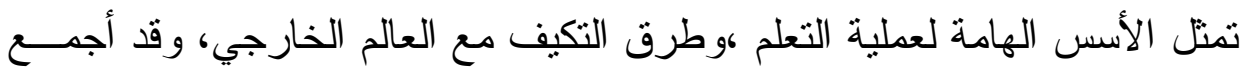
علماء النفس على أن الدو افع هي محركات السلوك اليومي.

ويعد الدو افع من أهم الموضوعات في علم النفس و التي حظيـــت باهتمــام

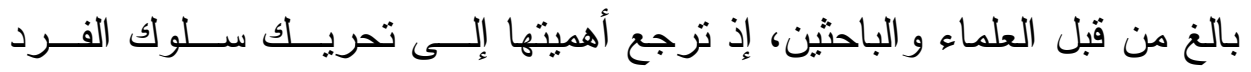
ونوجيهه للقيام بالمناشط و الممارسات جعلت موضوع الــدو افع محــل اهتمـــام المتخصصين وغير المتخصصين ،فمن منا لا يهمه معرفة دو افعه ودو افع غيره

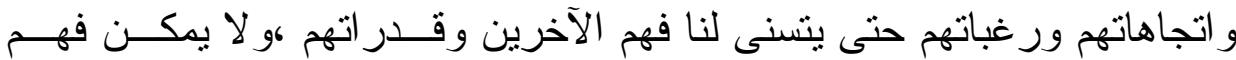

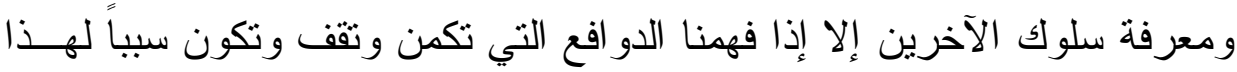

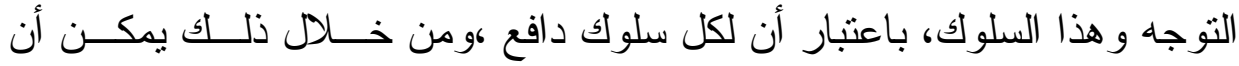
تزداد قدر اتتا على التحكم في السلوك وتوجيهه نوجيهاً سليماً.

وتمنل دافعية الإنجاز أحد الجو انب المهمة في منظومة الدو افع الإنسانية ،

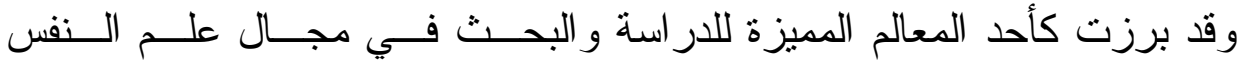
الاجتماعي و علم نفس الثخصية ، و أيضا في مجال التحصيل الدر اســي و الأداء المعملي في إطار علم النفس التزبوي ، ولما له من أهمية بالغة في تفهم الكثيـر من المشكلات التزبوية و التعليمية ، وبوجه عام قد حظي الدافع للإنجاز باهتمــام

"باحثت * 
أكبر بالمقارنة بالدو افع الاجتماعية الأخرى. (عبد اللطيف محمد خليفــة ،.... (17-10:

فدافع الإنجاز من الدوافع الخاصة بالإنسان ،ربما دون غيره من الكائنات

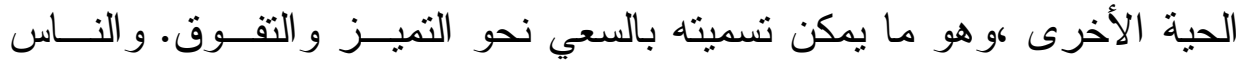

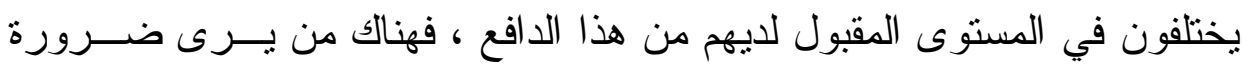

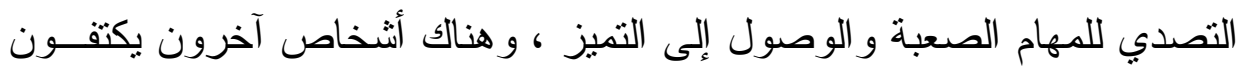

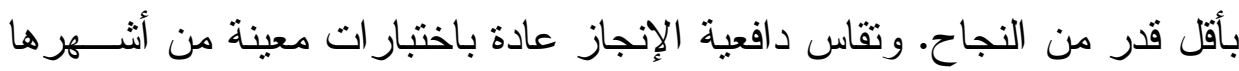
اختبار تفهم الموضوع (TAT) الذي يتطلب من النـاس أن يسـستجييو الثنلاتهـين

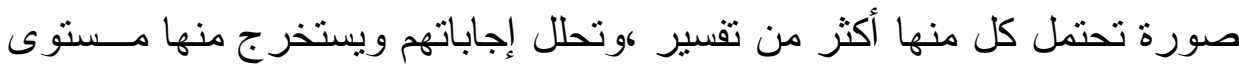
الإنجاز عند المستجيب. كما يمكن قياس دافعية الإنجاز من خلال المو اد المكتوبة

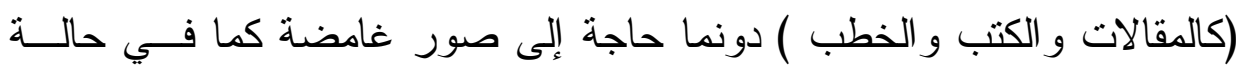
(TAT)

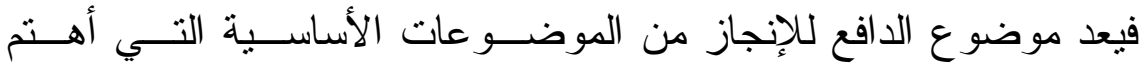

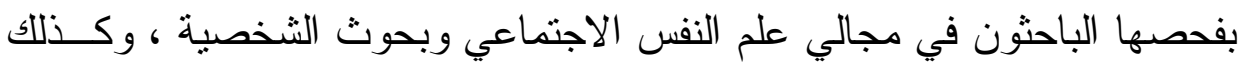

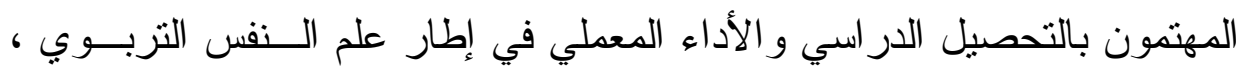

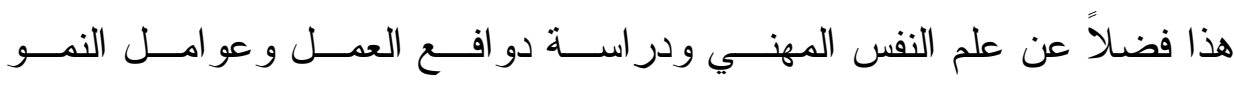

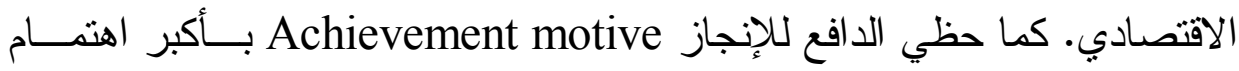

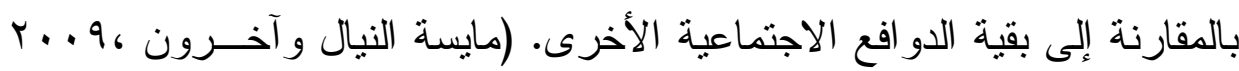

ويرجع الاهتمام بدر اسة دافع الإنجاز إلى أهميته في العديد من المجــالات

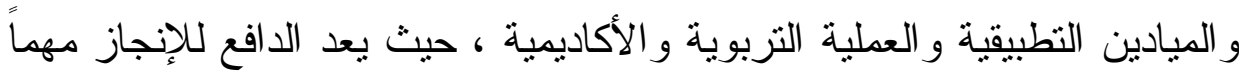

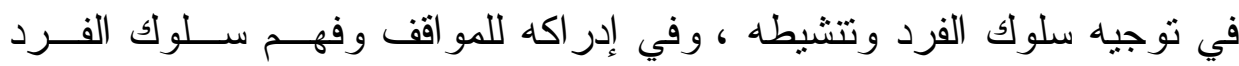




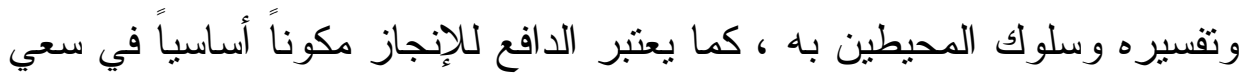

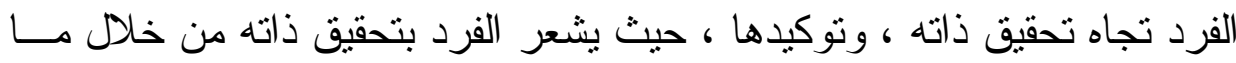

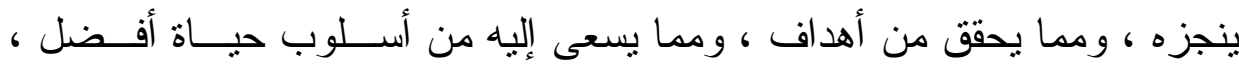
ومستويات أعظم لوجوده الإنساني. (Franken,Re ,1980: 19)

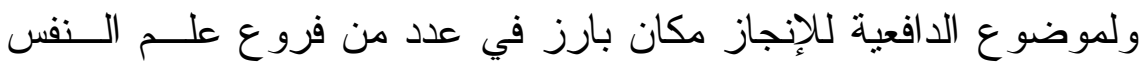

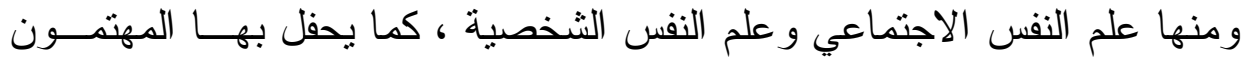
بالتحصيل الدراسي و الأداء المعملي في إطار علم النفس التربوي ، وذلك لما له

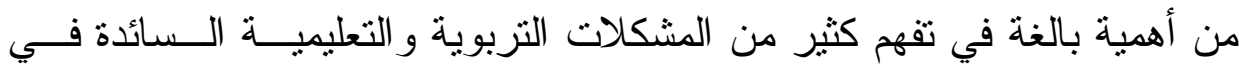
مختلف الثقافات ، وقد اتسع الاهتمام بالدافع للإنجاز بحيث درس فــي علاقتــهـ بمتغير ات نفسية و إكلينيكية واجتماعية مختلفة كالاتجاهات الثخصية ، و المعاملة الو الدية ، و التغيرات الانفعالية ، وسمات الثخصية ، و الفروق الثقافية. (مايسـسة واتية

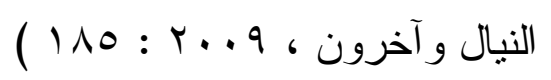
ويشير نبيه إسماعيل (1911 ) إلى أن الــدافع للإنجــاز مــن الــدوافع

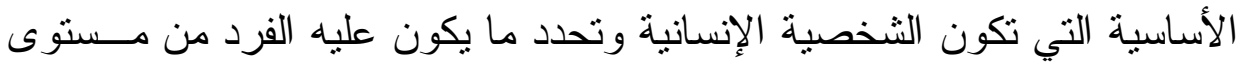

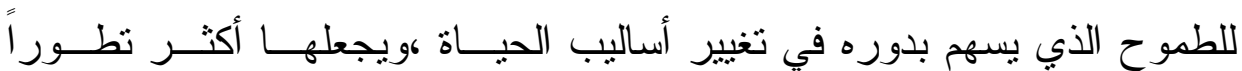
لمواجهة تحديات العصر ولذا فقد اعتبر علماء علم النفس أن دافع الإنجاز مـن فئن

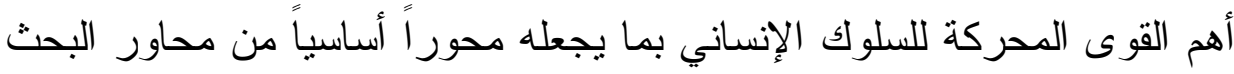

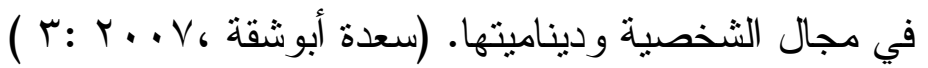
نبذة تاريخية لمفهوم دافع الإجاز :

ويرجع استخدام مصطلح دافع الإنجاز في علم النفس من الناحية التاريخية

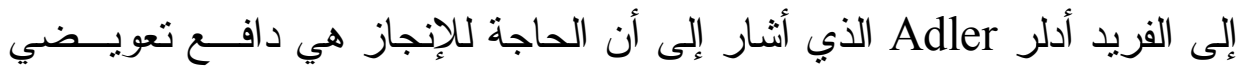

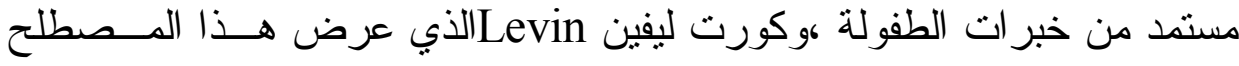


في ضوء تتاوله لمفهوم الطموح Aspiration. وذللك قبــل اســتخدام مــور اي ، واي

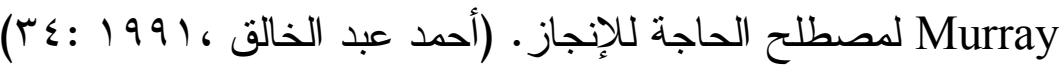

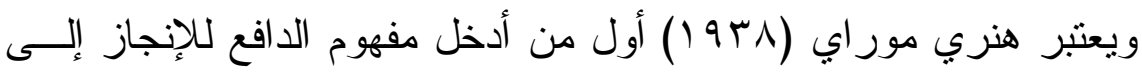

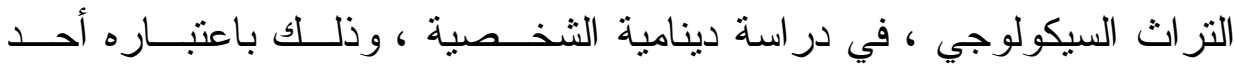

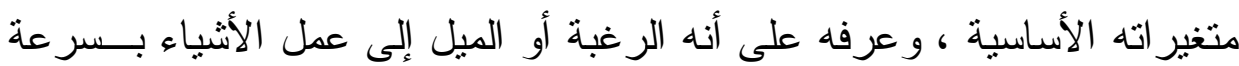

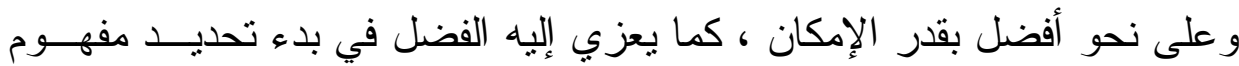

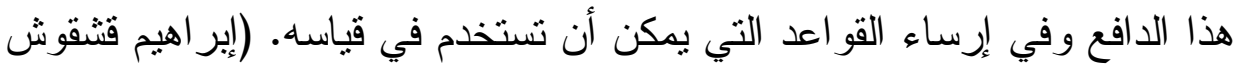

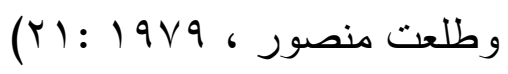

ويـــكر هنــري مــور اي 1938 و Murray و 1982 Ziegler الناحيــة

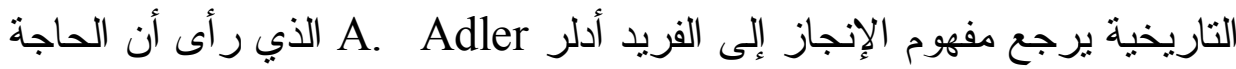

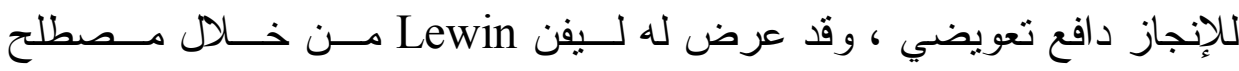

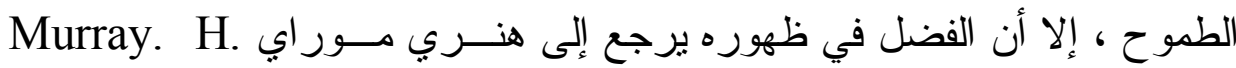

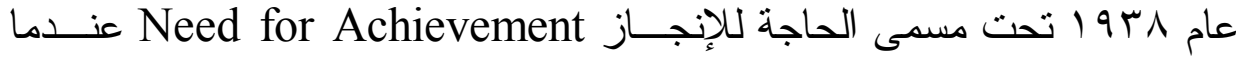

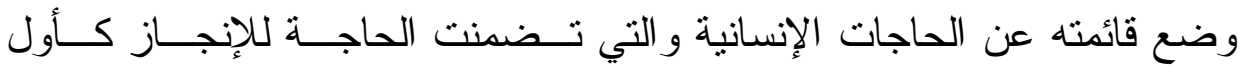

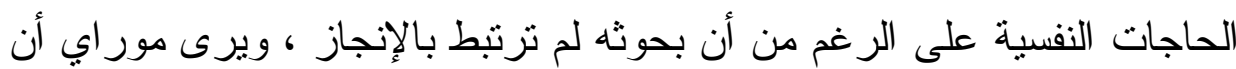

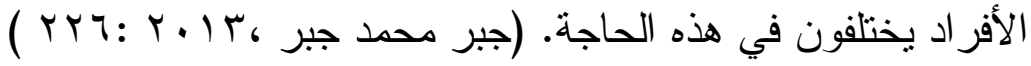
ونظر اً لما لدافع الإنجاز من أهمية كبيرة في بناء المجتمع ، نجد أن هناك لهاك

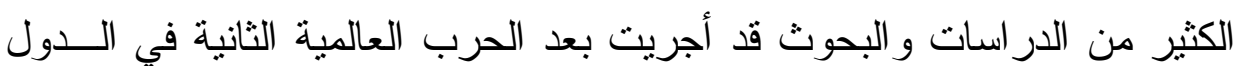

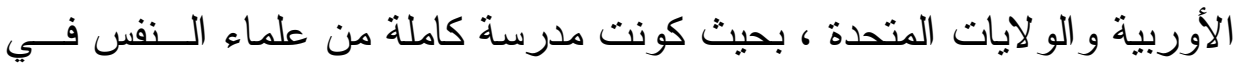

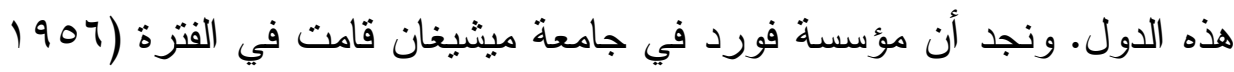

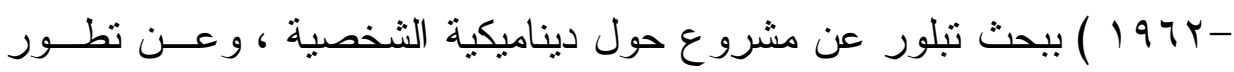

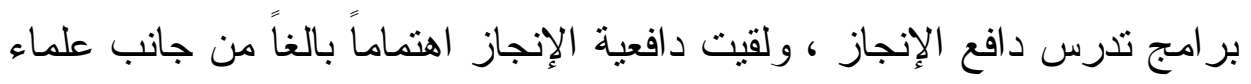


النفس حتى صار البحث في هذا الميدان من المعالم المميزة للفكر الـسيكولوجي

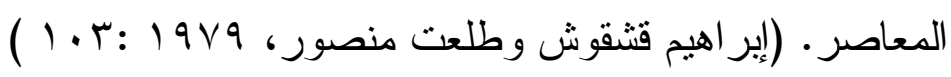

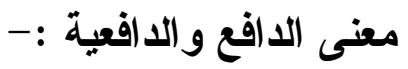

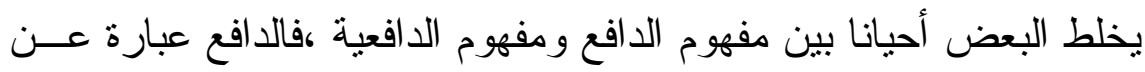

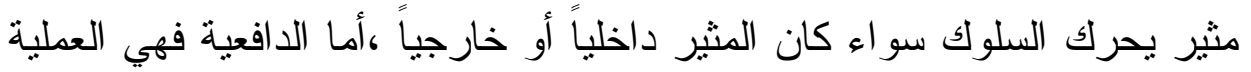

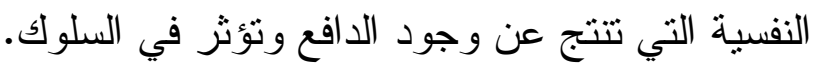
ويعرف أحمد عبد الخالق الدافع بأنه حالة من الإثارة أو التتبه داخل الكائن

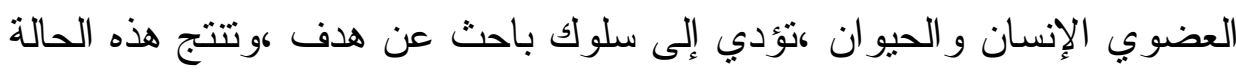
عن حاجة ما ،وتعمل على تحريك السلوك وتتشيطه وتوجيهه. (أحمد عبد الخالق القان ( 17$): 199)$.

بينما يرى عبد السلام عبد الغفار الدافع بأنه حالة نفسية تـستثير نــشاط

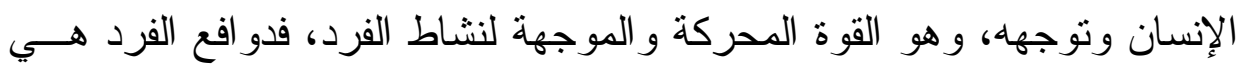

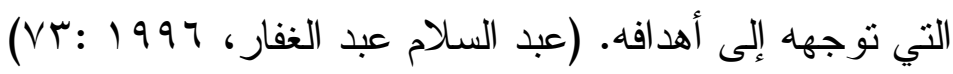
يعرفها مصطفى و أمينة بأنها حالة تغير نانشئه في نــشاط الكـائن الحسـي

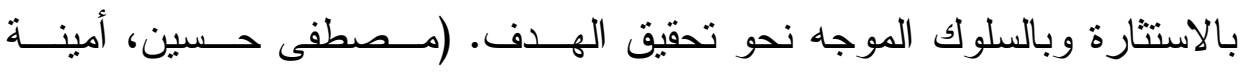

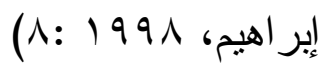

وينظر فرج عبد القادر طه إلى أن الدافع قوة بيولوجية نفسية داخل الفــرد

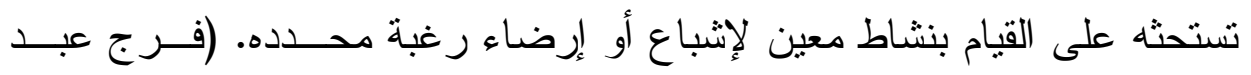

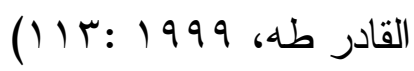


في حين يرى عبد اللطيف خليفة أن الدافع هو حالـــة تـــوتر أو اســتعداد

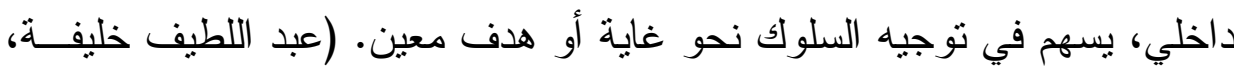

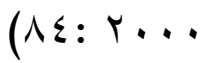

ويعرف يونج : P.t.Yong الدافعية بأنها عبارة عن حالة استثارة وتـــوتر

Staats : داخلي تثير السلوك وتدفعه إلى تحقيق هدف معين. ويعرفها سـتانس الدافعية بأنها تثريط انفعالي لمنبهات محددة ومركبة، يو اجهها مصدر التـدعيم. كما عرف هب Hebb الدافعية بأنها أثزر لحدثين حسيين هما الوظيفة المعرفيــة التي توجه السلوك، ووظيفة التيقظ أو الاستثارة التي تمد الفرد بطاقـــة الحركـــة.

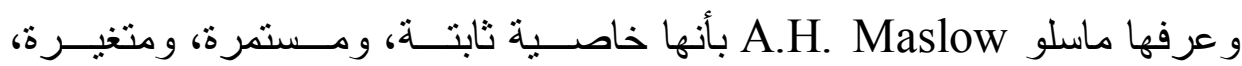

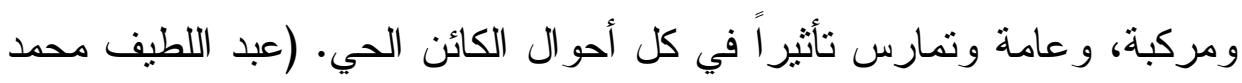

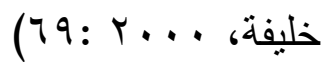

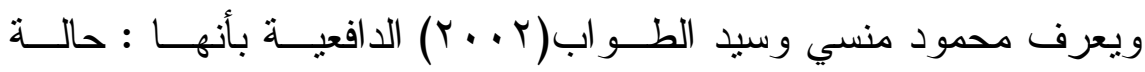

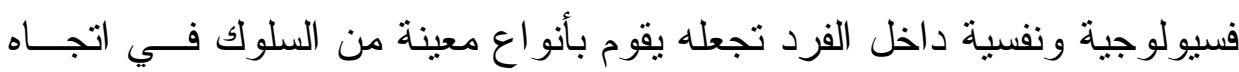

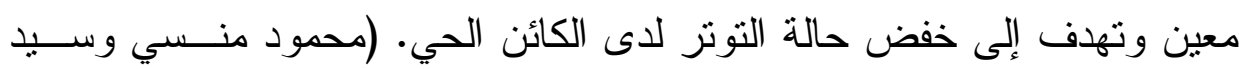

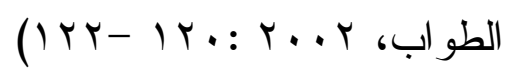

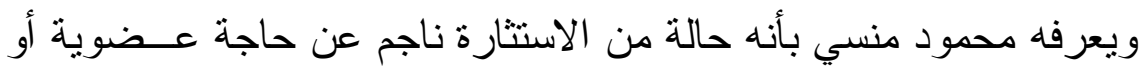

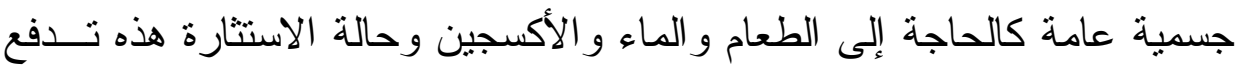

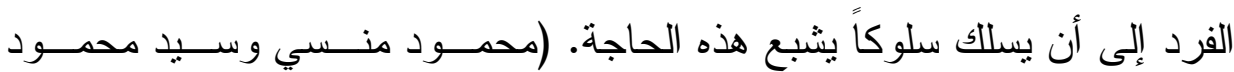

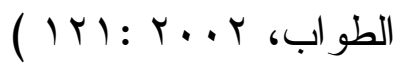
بينما تعرفها شادية أحمد و آخرون بأنها : عملية، أو سلسلة من العمليـات، تعمل على إثارة السلوك الموجه نحو هدف وصيانته و المحافظة عليه، و إيقافه في

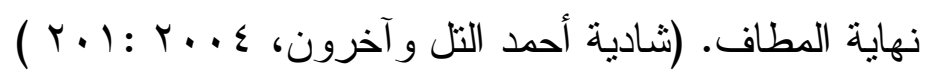


ويرى سليمان عبد الواحد الدافع بأنه حالة داخلية تحرك السلوك وتوجهـهـ

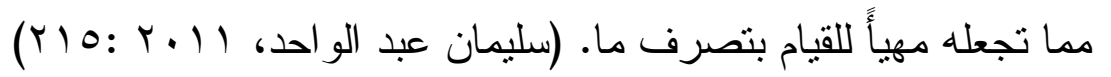

$$
\text { أنواع الدوافع وتصنيفها :- }
$$

دو افع الإنسان كثيرة ومنتوعة لا يكاد يبلغها الحصر، ولسهولة عرضـهـا

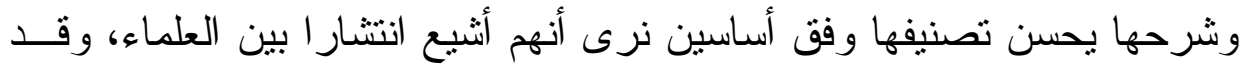

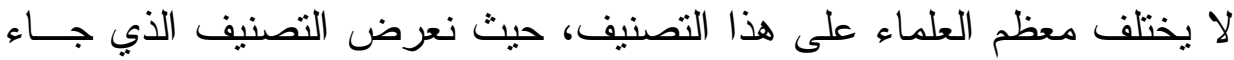

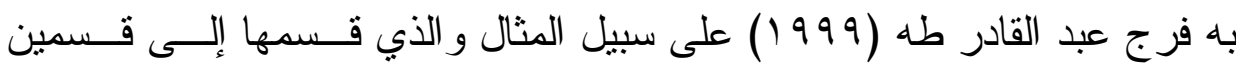
كبيرين هما :

\section{1-الدوافع الأولية أو الفطرية primary motives}

وهي مجموعة من الدو افع غرست في الكائن الحي، إنساناً كان أم حيو اناً،

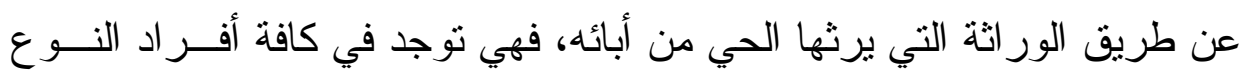

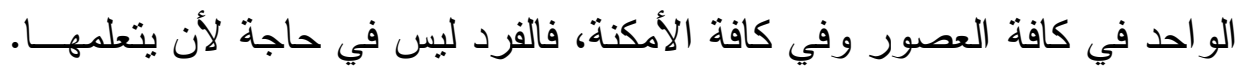

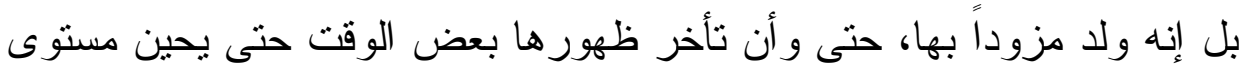

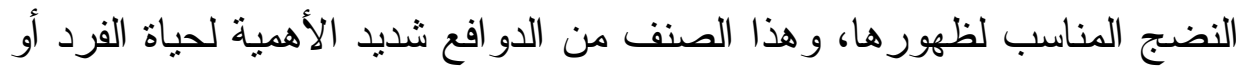

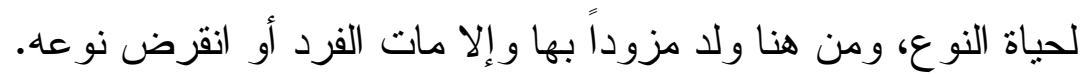

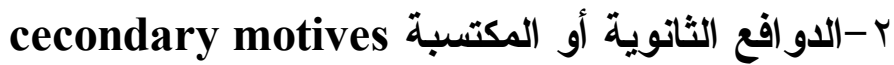

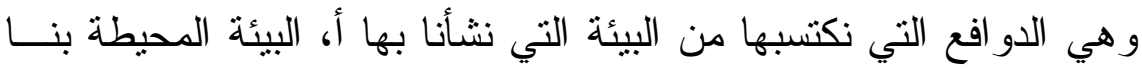

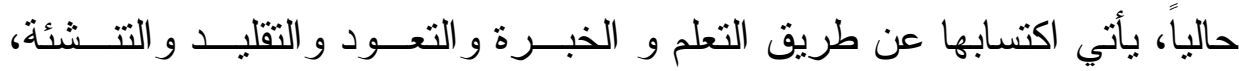
وتجارب الفرد و احتكاكه بوسطه وبيئته الخاصة، ومن هنا كان اختلاف كل منـــا

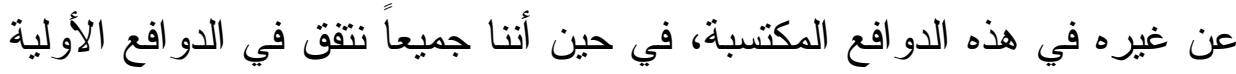

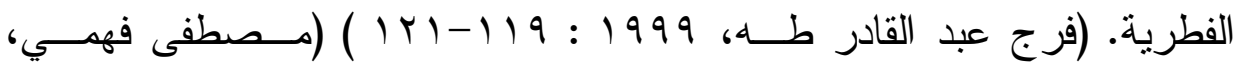

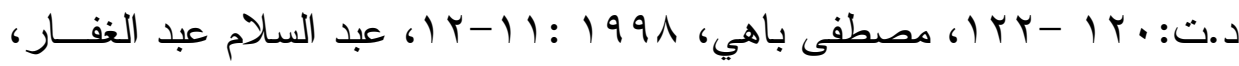

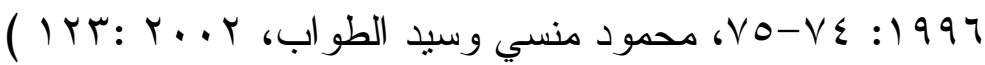

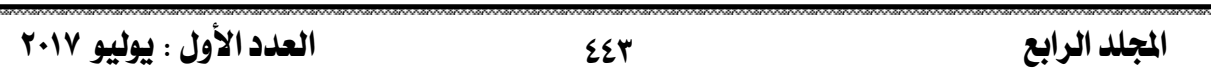




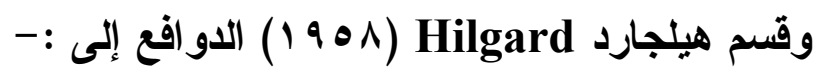

الدو الدع اللازمة لبقاء الفرد.

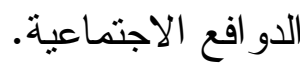

الدو افع المرتبطة بتكامل الذات : أطلق عليها هليجارد اسم الحاجات التي

تتعلق بالمركز ، كما يمكن تصنيف الدو افع إلى : الإنى

$$
\text { r ا. الدو افع الثعورية والأولية و الثانوية. }
$$

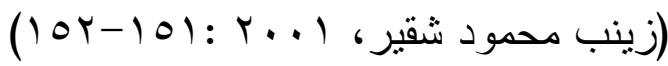

$$
\text { وهناك تصنيف آخر للاو افع : }
$$

• دوافع فسيولوجية وسيلية أو أولية Psychological

$$
\text { Motivations }
$$

• دوافع سيكولوجية ثانوية Secondary Psychological Motivations

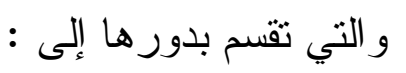

أ- الدوافع الداخلية الفردية / تتمثل في سعي الفرد إلى القيام بشيء معين

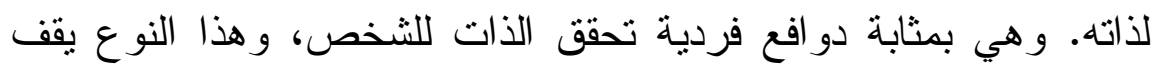

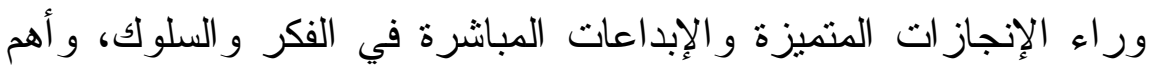

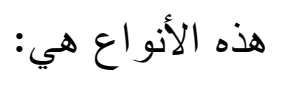

- دافع الفضول :هو حب الاسنطلاع و الرغبة في استكثاف معالم البيئة. - دافع الكفاءة :مرتبط بدافع الفضول ويسهم في تحقيق أفضل نمو و ارتقاء و استغلال لقدر اته من أجل مو اجهة منطلبات البيئة التي يعيش فئها. - دافع الإجاز :هو جهاد الفرد للمحافظة على مكانة عالية حسب قدر اته في كل الأنشطة التي يمارسها، و التي يحقق بها معايير التفوق على التى التهالئ أقر انه، حيث يكون القيام بهذه الأنشطة مرتبطاً بالنجاح و الفشل. بهائ. 
ب- الدوافع الخارجية الاجتماعية / هي الدو افع التي تتشأ نتيجة لعلاقة الفرد

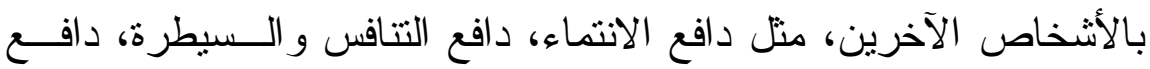

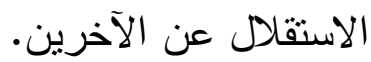

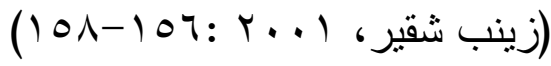

وقد ميز فيروف veroff بين نوعين من دافع الإجاز هما :

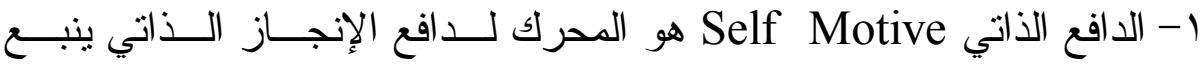

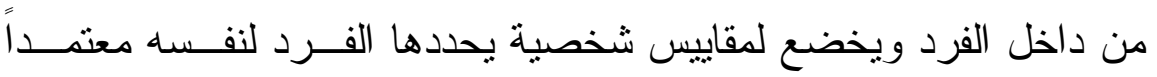

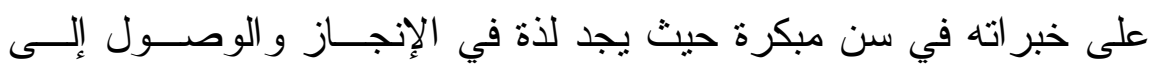
الهدف.

r- الدافع الاجتماعي Social Motive هو المحرك للدافع الاجتماعي يخضع

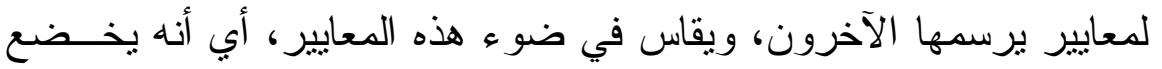

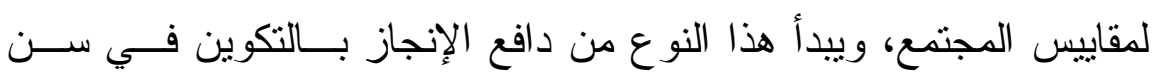

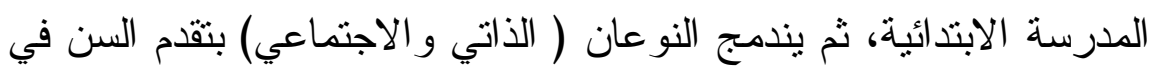

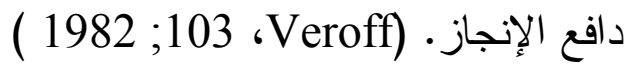

إن دافع الإنجاز دافع متعلم ومكتسب ينمو ويتلور خلال عمليــة التتـشئة الاجتماعية، ويعني الرغبة في التفوق على الآخرين و إرضاء الـــات، وتخطيــي

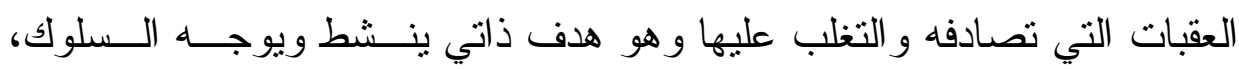

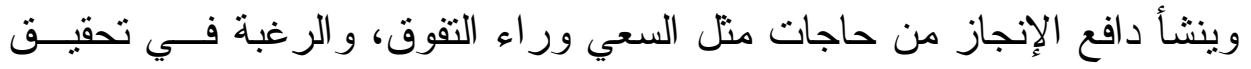

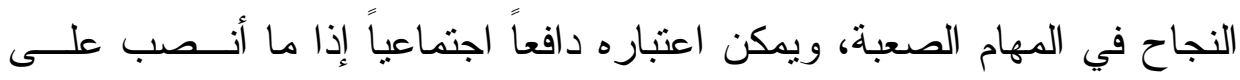

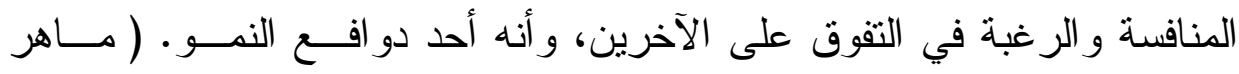

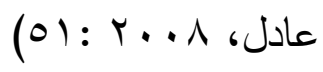




\section{مفهوم دافع الإججاز :-}

يعد مصطلح الدافع للإنجاز من المصطلحات الثائعة في مجال علم النفس التزبوي، ولذلك تعددت التعريفات بشأنه نظر اً لتعدد وجهات النظر اتجـــاه هــــا الدافع الذي يشكل التنظيم النفسي للطالب، ويحدد نشاطه نحو متطلبــات حياتــهـ الدر اسية.

\section{وفيما يلي نحاول عرض بعض من هذه التعريفات :}

وفي موسوعة علم النفس و التحليل النفسي يشير إلى رغبة الفــرد و ميلـــــ

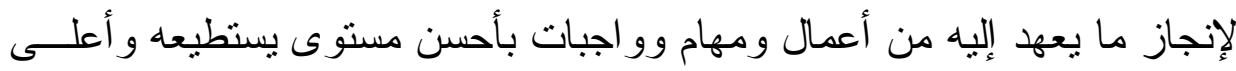

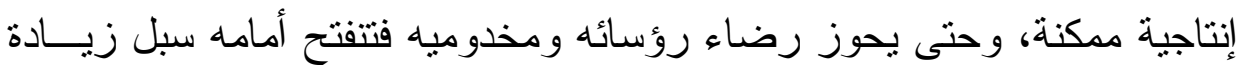
الدخل، ويسهل أمامه سبيل التزقي و التقدم على نحو ما يوجد لدى بعض رؤس والعاملين و الموظفين. ( فرج عبد القادر طه، rو 199 :

في معجم علم النفس المعاصر يعرف دافع الإنجاز بأنه. حاجة الـشخص

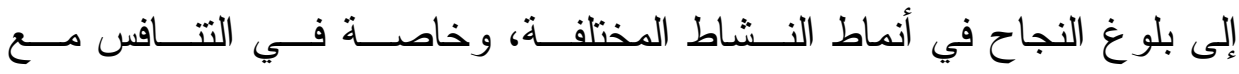

$$
\text { الآخرين.(سعد الفيشاوي، } 997 \text { ( }
$$

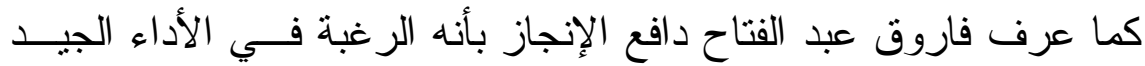
وتحقيق النجاح و هو هدف ذاتي ينشط ويوجه السلوك ويعتبــر مــن المكونــات الهامة للنجاح المدرسي. (فاروق عبد الفتاح موسى، (919 1 :0) ويعرفه أحمد عبد الخالق بأنه الأداء على ضوء مستوى الامتياز و التفــوق

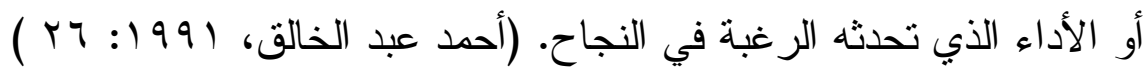
ويعرفه عبد السلام عبد الغفار بأنه تهيؤ ثابت نسبياً في الثخصية يحـدد مدى سعي الفرد ومثابرته في سبيل تحقيق أو بلوغ نجاح يتزثب عليه نوع مــن 
الإثباع، وذلك في المو اقف التي تتضمن الأداء في ضوء محدد للامنياز • (عبــــا

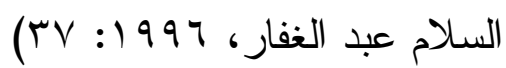

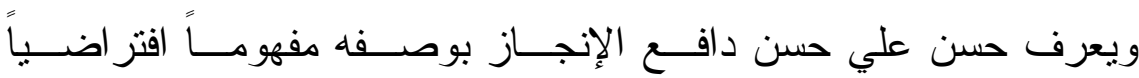

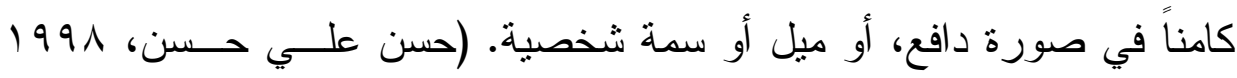
$(v \cdot$ :

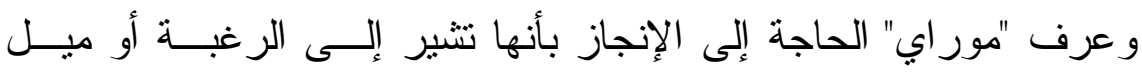

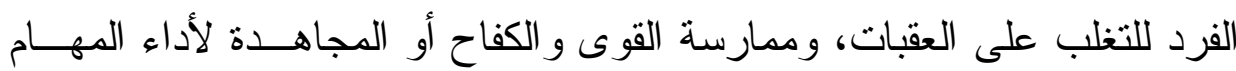

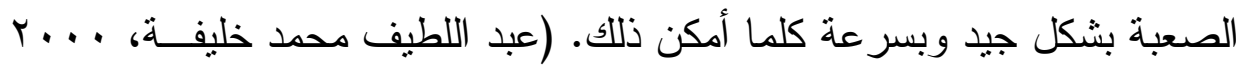

ويعرف عبد اللطيف خليفة الدافع للإنجاز بأنـــهـ اســتعداد الفـرد لتحمــل

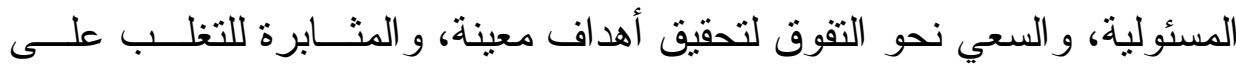

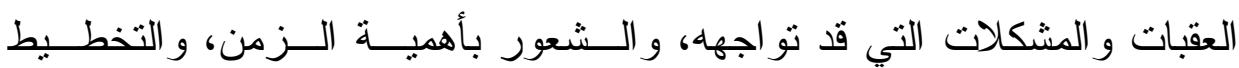

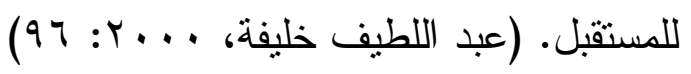

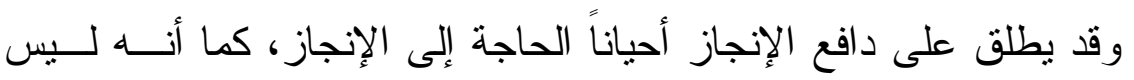

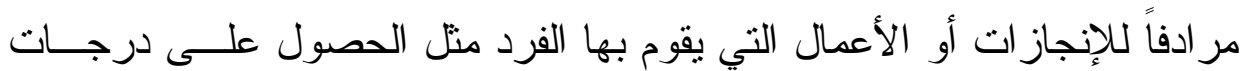

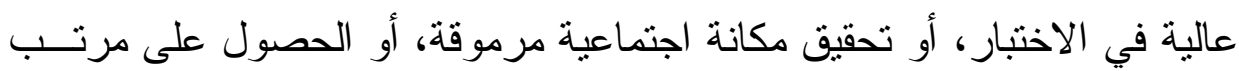

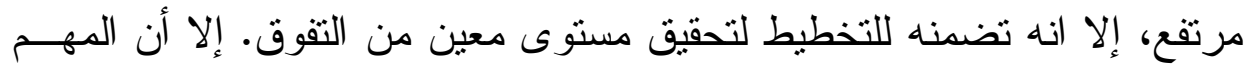

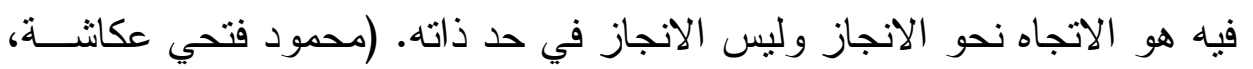
( $101-10 \mathrm{~V}:$ :...) ويرى محمود عكانشة الدافع للإنجاز هو حالة داخلية مرتبطـــة بمـشـاعر

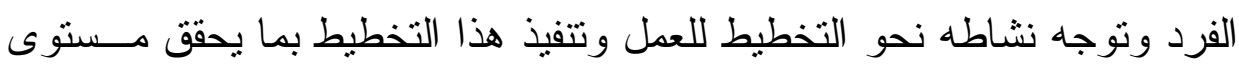

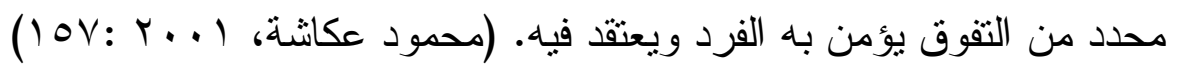


ويرى محمود منسي (أن دافعية الإنجاز هو كفــاح الفــرد لأداء الدهــام

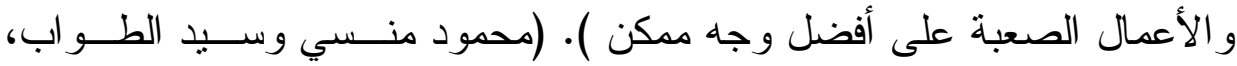

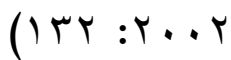

وترى سعده أحمد. إن الدافع للإنجاز كأي دافع آخر يتـــمن الجوانــب

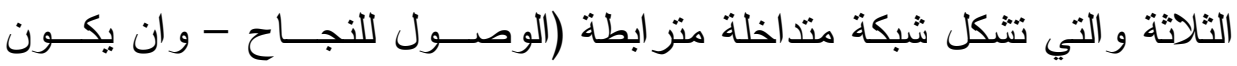

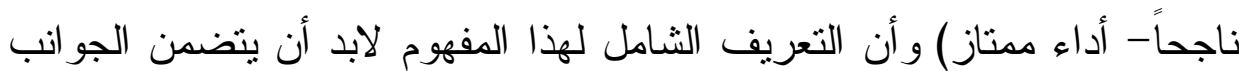

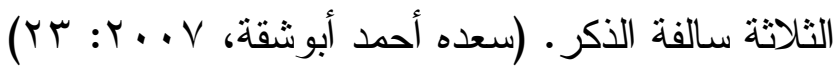
ويعرف (جونسسون و ماكيلانـــ Johnson \& meclelland ) الـــــع

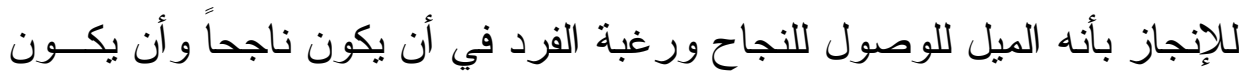

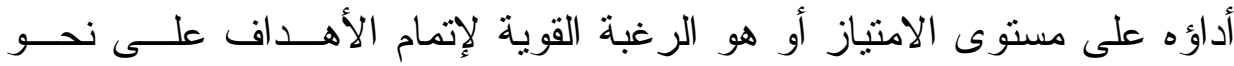

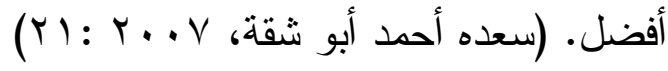

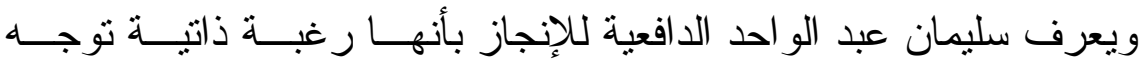

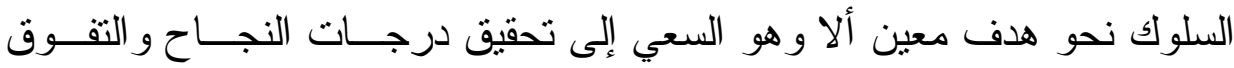

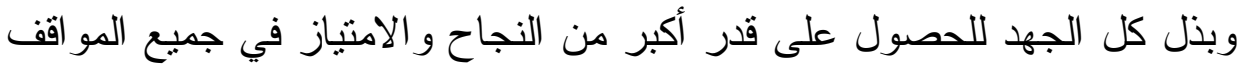

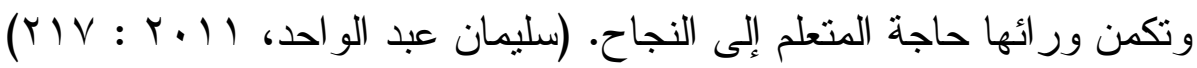
ويعرفه جبر محمد (r (ب) بأنه رغبة الفرد وسعيه المستمر نحو إنجساز

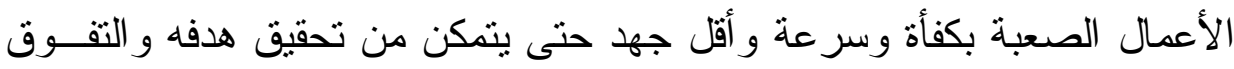

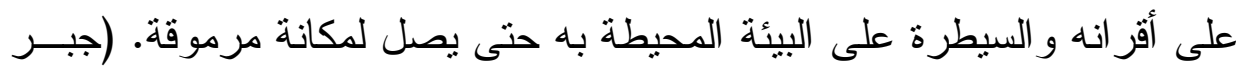

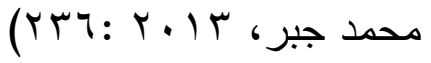

بينما تعرف إيمان عبد المقصود(r (ب) دافع الإنجاز بأنه رغبة ملحسـة داخل الفرد تدفعه للوصول إلى مستويات عالية من الامنياز و التفوق مما يــؤدي

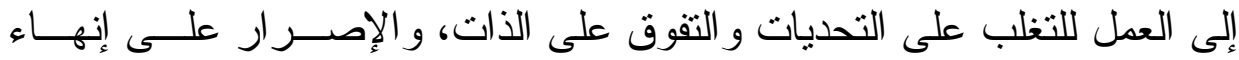




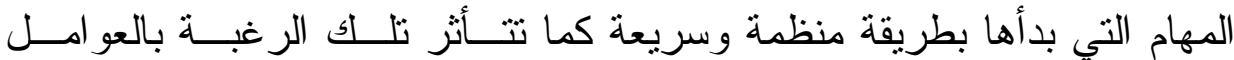

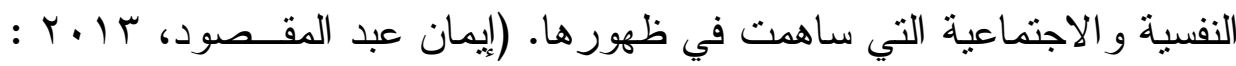
(IV.

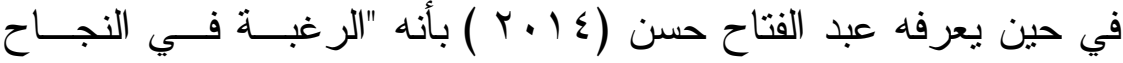

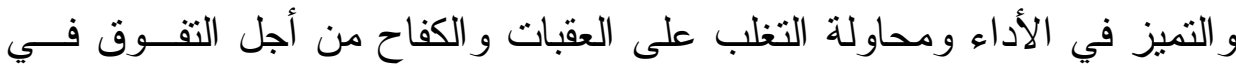

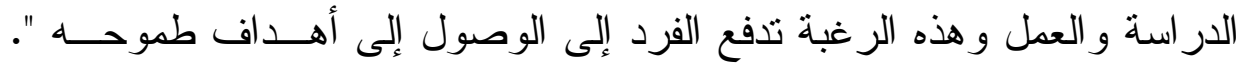

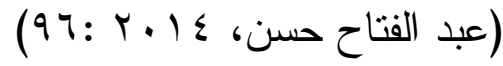

وترى الباحثة من خلال عرض كل التعريفات السابقة لدافع الإنجاز بأنــهـ

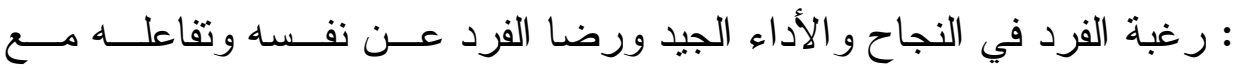
الآخرين ومع البيئة التي يعيش فيها.

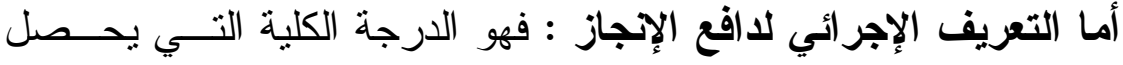
عليها المستجيب من خلال إجابته على فقر ات مقياس الدافع للإنجاز الذي أعدتــهـ الباحثة و المعتمد في الدر اسة الحالية.

\section{تعليق عام على التعريفات التي تناولت الدافعية للإجاز :-}

نلاحظ من خلال عرض التعريفات السابقة و الخاصة بدافعيــة الإنجــاز

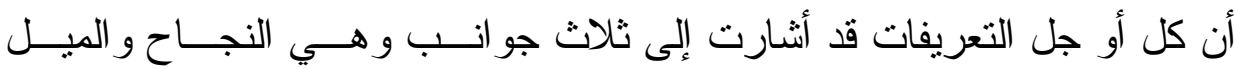

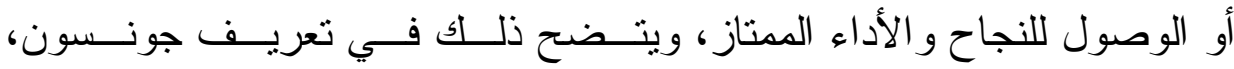

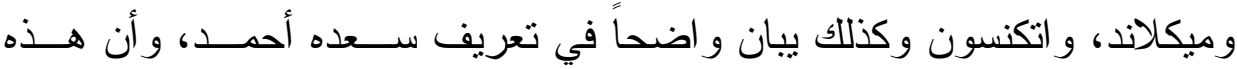

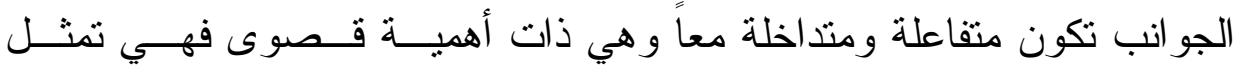

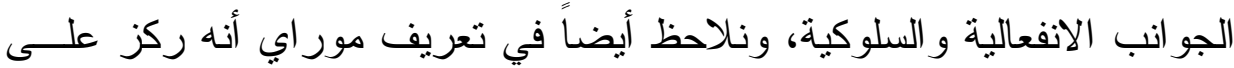

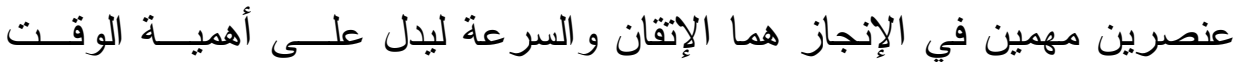

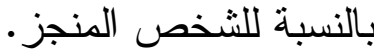




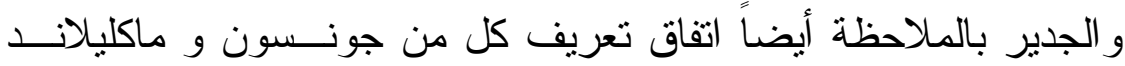

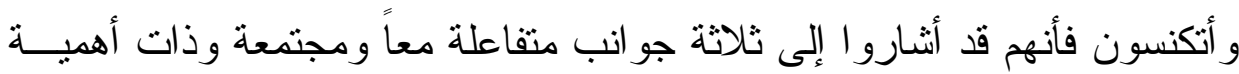

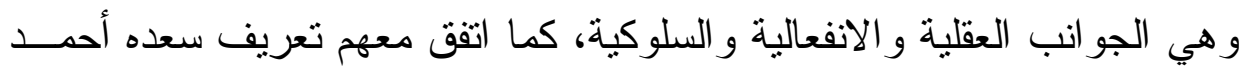

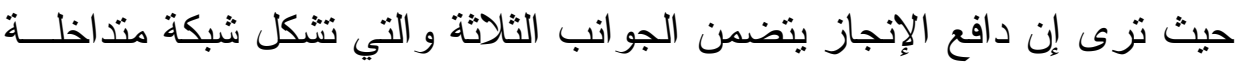

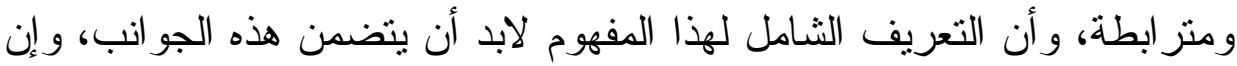

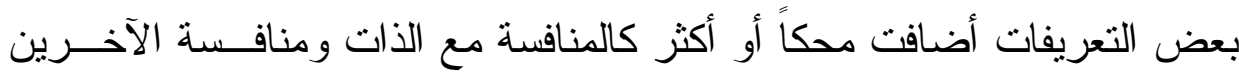
كما جاء في تعريف فرج عبد القادر طه وسعد الفيشاوي. خصائص الثخص المنجز :-

يتميز الثخص المنجز في نظر بعض علماء النفس بأنه الثخص الـــي

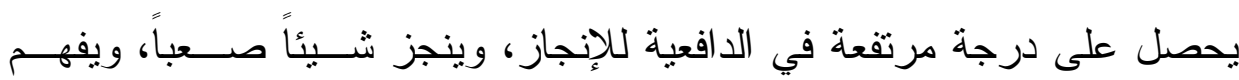

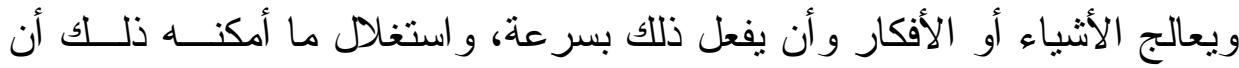

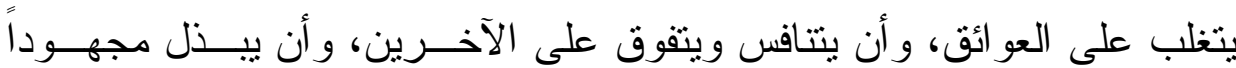

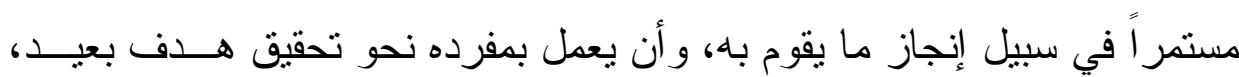

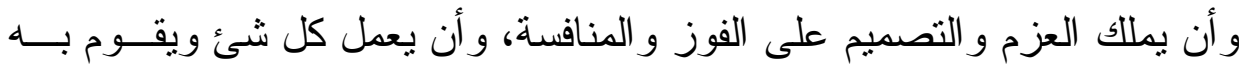
بصورة جيده، وأن يجاهد في سبيل التغلب على الضجر و والتعـب (31) 1972: (McClelland, D.c,

ونحاول هنا أن نعرض خصائص الثخص المنجز حسب آراء بعض الباحثين : • إن الثخص المنجز يميل إلى بذل محاو لات جادة للحصول على قدر كبير

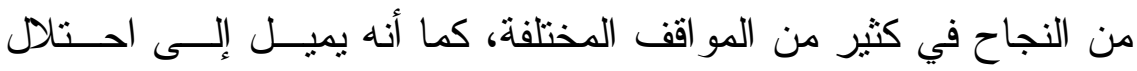

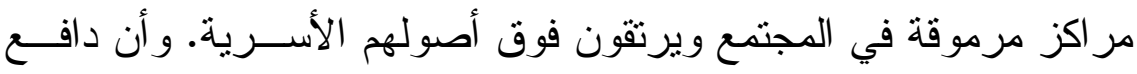

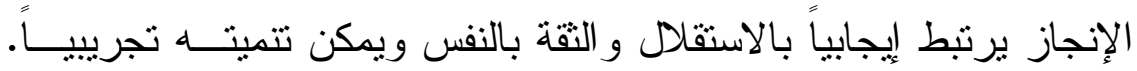

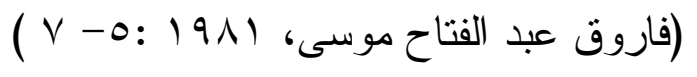


الذي يتميز بدافع مرتفع من الإنجاز يعتمد على جهده الثخصي وقدرتــهـ

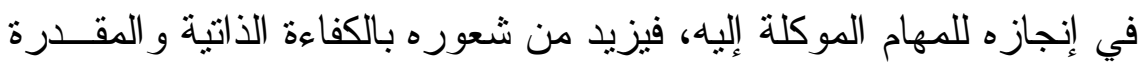

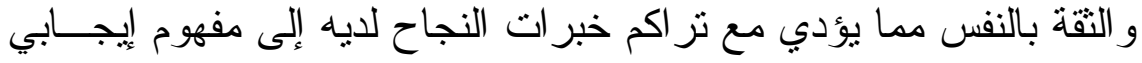
عن ذاته يرفع من تقديره لها، في حين إن الطالب إذا اعتمد على مساعدة

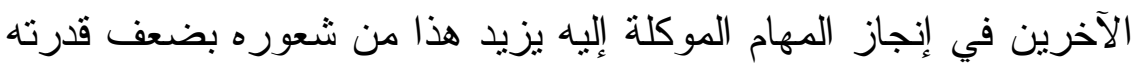

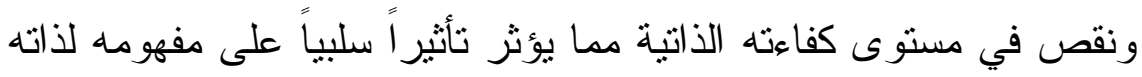

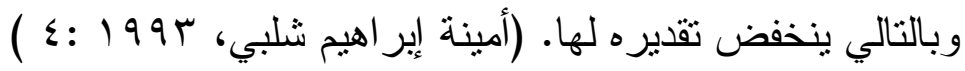
الثنعور بالمسؤولية، و السعي نحو التفوق لتحقيق مستوى طموح مرتفــع،

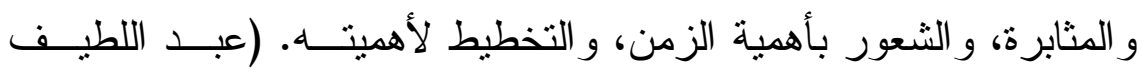

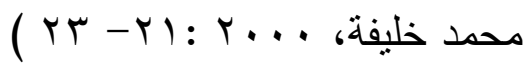

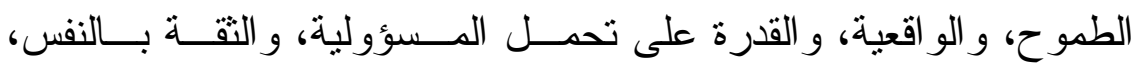

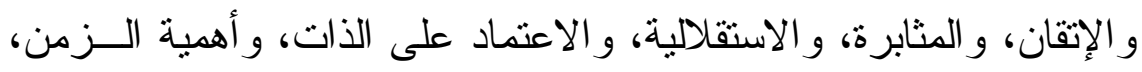

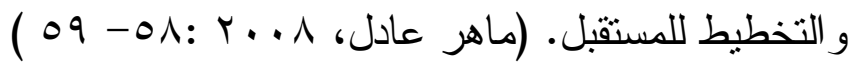
إن الأفر اد ذوي الدافعية المرتفعة للإنجاز يختلفـــون عـنـ الأفـــر اد ذوي

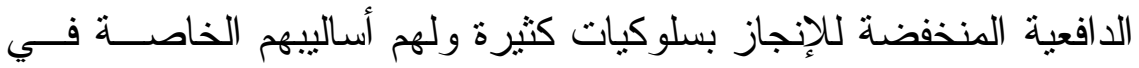

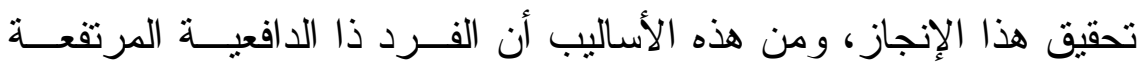

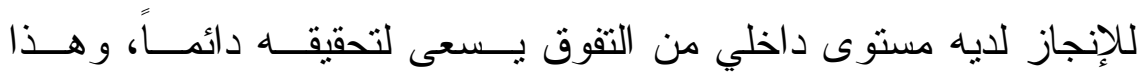

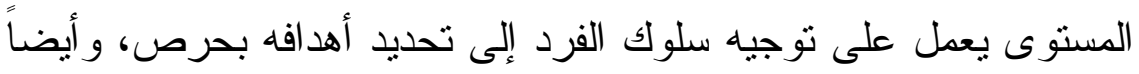

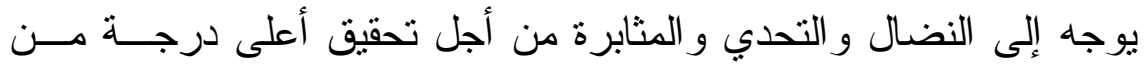

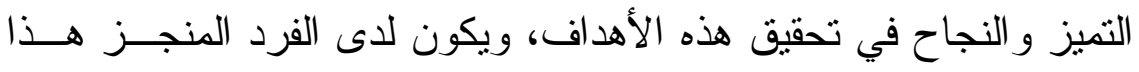

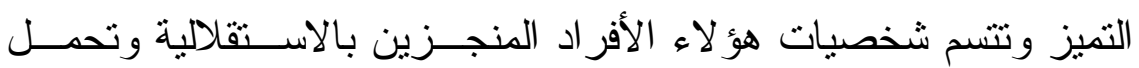


المسؤولية الثخصية لنواتج جميع أنثطتهم. (نشوة حافظ عبــــ اللطيــف،

$$
(r V: r \ldots q
$$

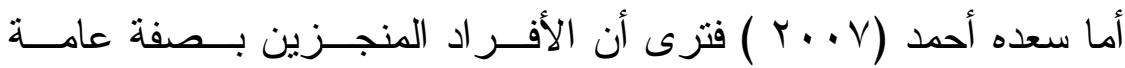
و التلاميذ بصفة خاصة يميلون إلى السلوك و التصرف بطرق محدده أو بأسـاليب

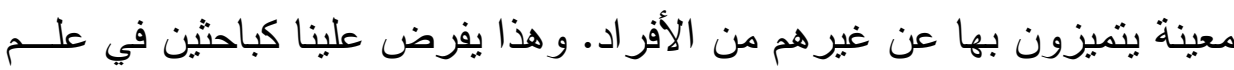
النفس تتجيع وتتمية الصفات الإيجابية التي سبق ذكرها لإى الصغار و الكبــــار.

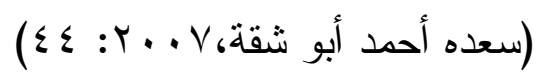

ويرى سليمان عبد الواحد (11 + r) أن هناك صفات أخرى يتميزون بهــا

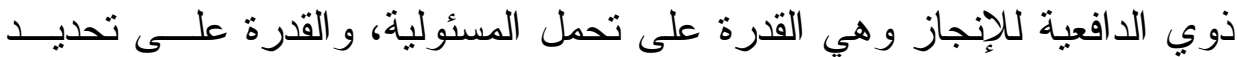
الأهداف، و القدرة على استكثاف البيئة، و القدرة على التخطيط لتحقيق الهدف، و

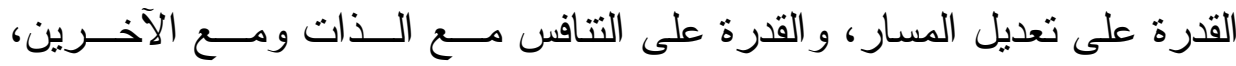

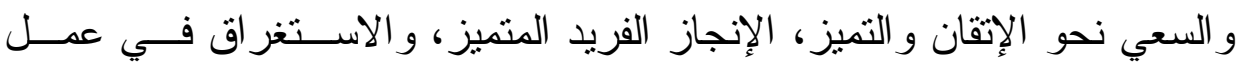

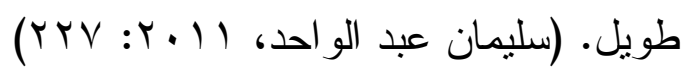

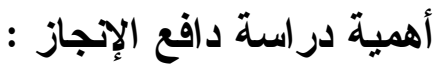

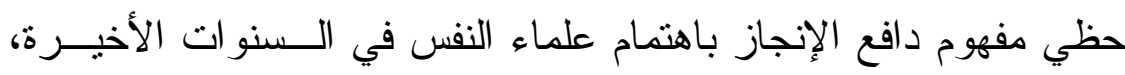
وهو الميل الدافعي الذي يثير استجابات توقع الهدف الايجابية أو السلبية، التـي فالتياهي

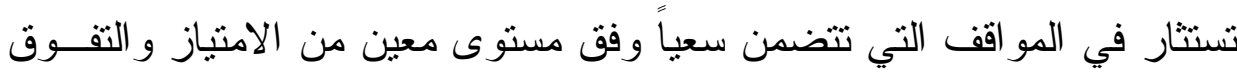

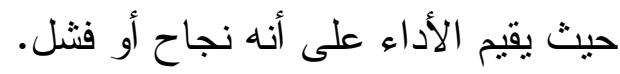

ودافع الإنجاز سمة دينامية تكمن داخل الفرد تستثير فيه الحركة والنشاط

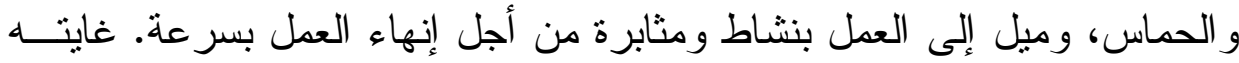
في ذلك الوصول إلي إنهاء ما يؤديه الثخص من المو اقف التي تتــضمن ســعياً 
وفق مستوى معين من الامتياز أو التفوق حيث يقيم الأداء على انسـهـ نجــاح أو

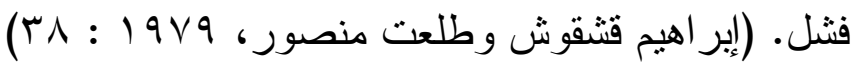
كما تلعب الدو افع دوراً مهماً ومستمر اً في معظم نواحي التعلم الإنسـساني

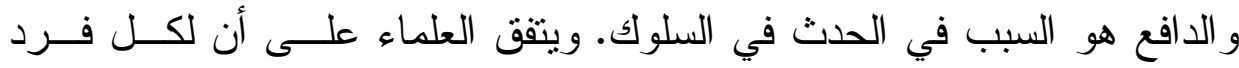

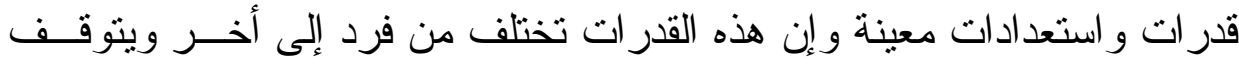

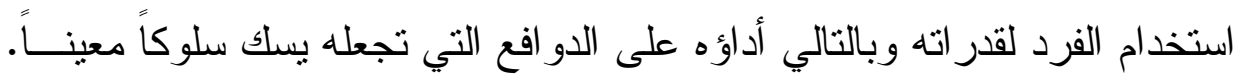

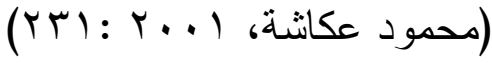

ودافع الإنجاز ليس من الثروط الضرورية لبدء الــتعلم فحسب، بــلـ

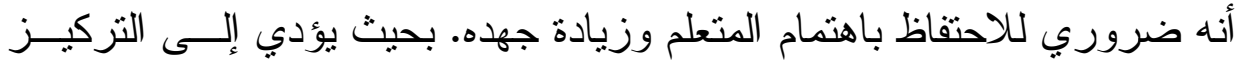

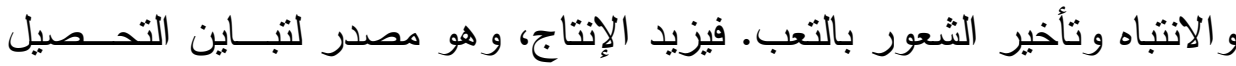

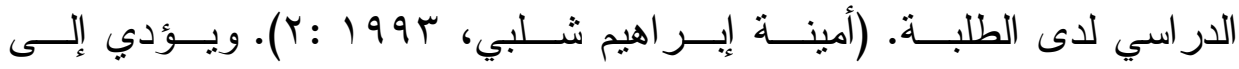

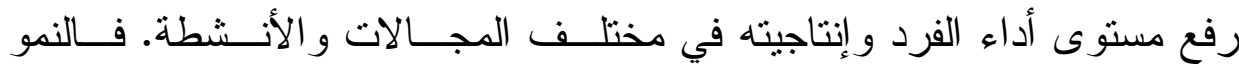

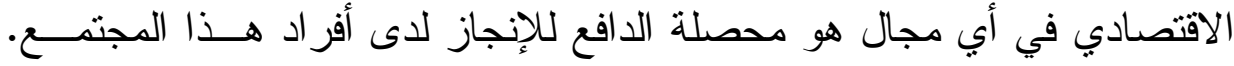

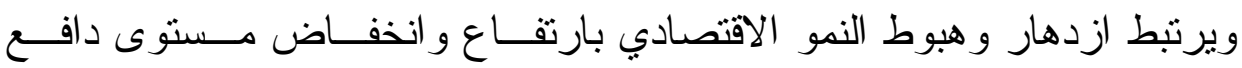
الإنجاز. حيث يحول ضعف التوجه الإنجاز دون بذل الجها ونكريس الطاقة في

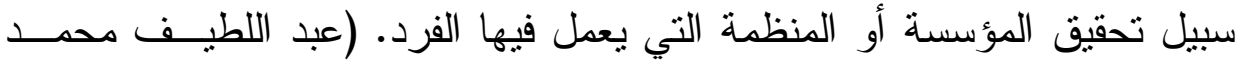

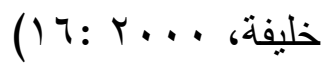

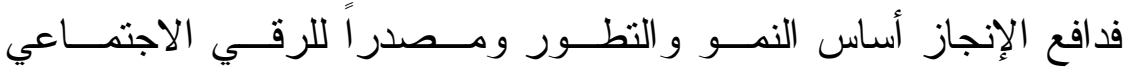

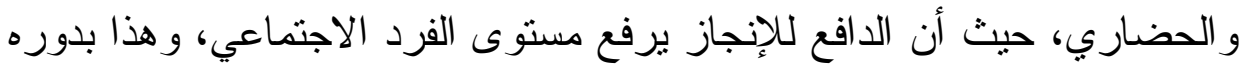

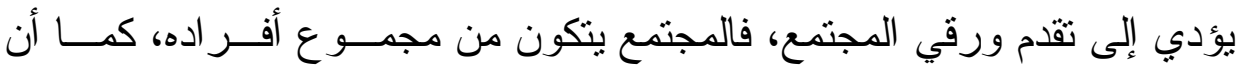

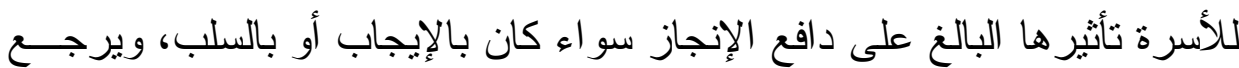

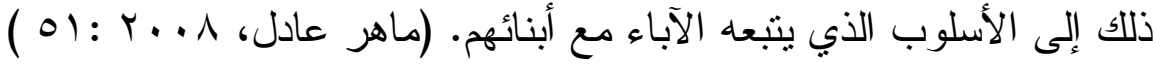


كما تلعب دافعية الإنجاز دوراً مهماً وخطيراً في رفع مستوى أداء الفــرد

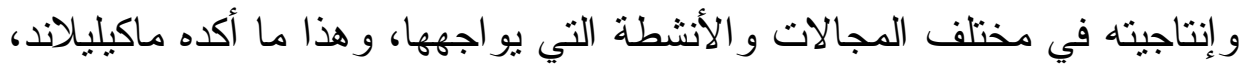
حين رأى أن مستوى دافعية الإنجاز الموجود في أي مجتمع هو حصيلة الطريقة

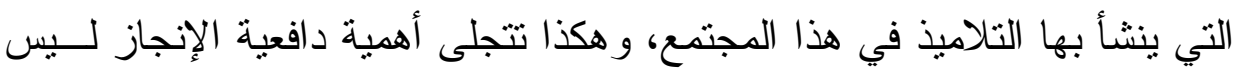

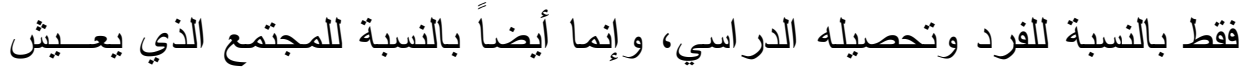

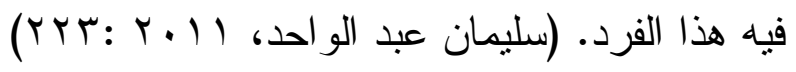
تأثير الضغوط النفسية على دافع الإنجاز :

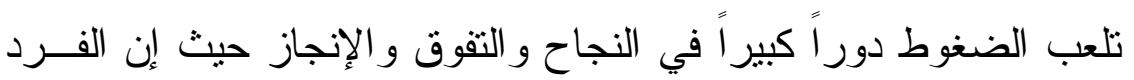

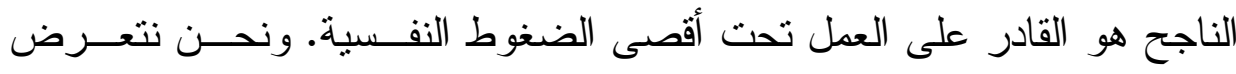

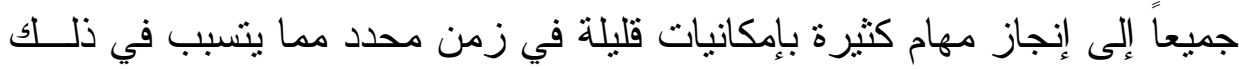

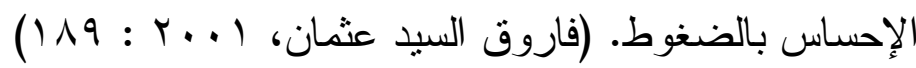

تأثر دافع الإنجاز بالانفعالات الني يتم إثارتها من خلال التعزيزات التــي

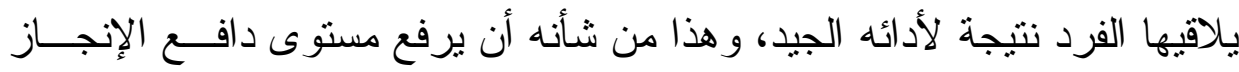

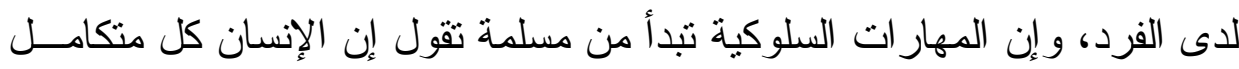
يؤثر ويتأثز بكل ما يحيط به. فعندما تكون الاتجاهات إيجابية فأننا نستطيع إنجاز

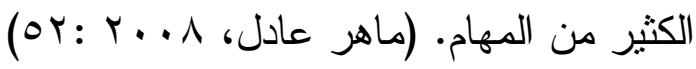
ويتعرض الطلاب عادة لضغوط نفسية فـي حيــاتهم الار اســية، وهــــهـ

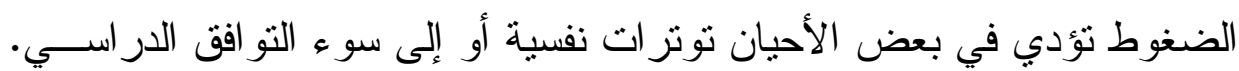

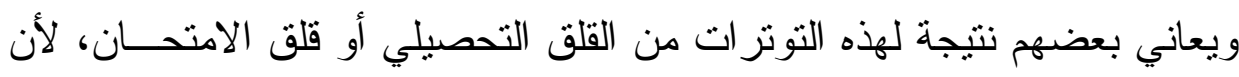

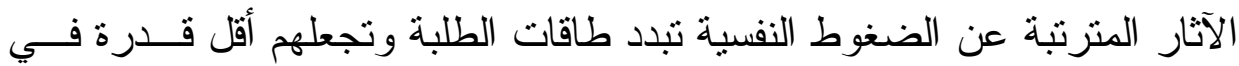

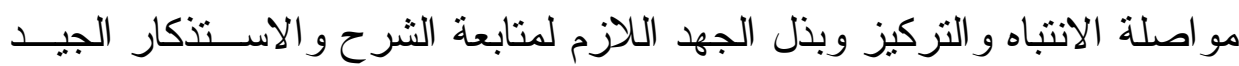
الفعال مما أثز في إنجاز هم الدراسي وتسبب في اضطر اب علاقاتهم مع زملائهم 
ومدرسيهم. (فرج عبد القادر طه، 999 (1: 19، محمــد عبــد الظــاهر وســيد

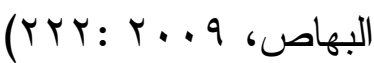

تعتبر الضغوط النفسية العامل الرئيسي في المشكلات التنظيمية خاصــة مشكلة الأداء المنخفض ودور ات العمل و التغيب. وتبدو العلاقة بـين الــضغوط

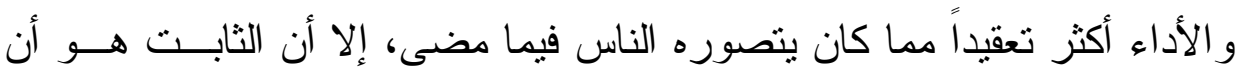
وجود مقدار معقول ومناسب من الضغوط يجعل الأفر اد يشعرون بالتونز ، الأمر إلى الذي يدفعهم ويحمسهم لكي يسيطروا ويتحكمو ا في هذا التونز مما يزيد الرغبـــة في الإنجاز • و إن وجود مقدار معقول من الضغوط يجعل إفراز مادة (الأدرينالين

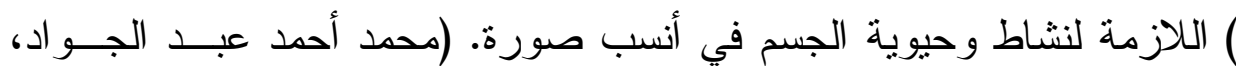
$(O r: r \cdot \Lambda$ دافعية الإنجاز و التعلم :- 2 - 2

إذا نظرنا إلى علاقة عامة والدافع للإنجاز خاصة مــن حيــث العمليــة التزبوية فإننا نجد المربيين قد اعتقدو الفترة طويلة أن الثواب و العقاب لهما قــدر

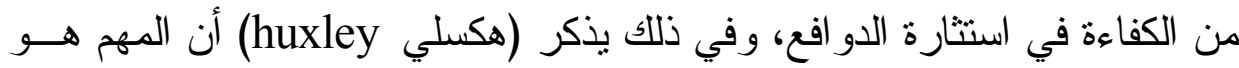
دفع التلاميذ إلى القيام ببعض المجهود العقلي تجاه التعلم، ولكن الـسؤ ال الــذي يتبادر إلى الذهن هنا هو كيف ندفع الأطفال لمحاولة التعلم ؟ إن الإنسان يتعلم إذا أر اد أن يتعلم وكانت له القدرة على التعلم وســـــ له الفرصة للتعلم وقدم لله النصح و الإرشاد، غير أن القدرة و الفرصة و الإرشــاد

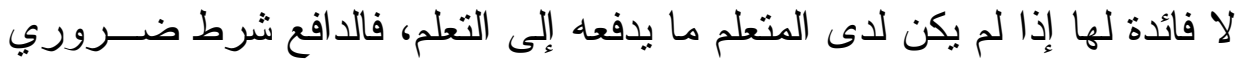

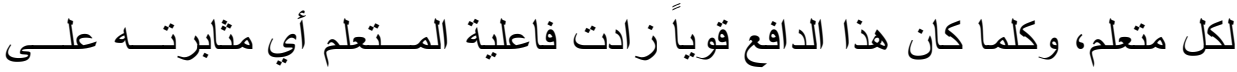
التعلم و الاهتمام به، وقد أثتتت العديد من الدر اسات أن الدافع للإنجــاز مــصدر لأحداث تغيير كبير في تحصيل المتعلم كما أنه مــصدر لاخــناف المتعلمــين 


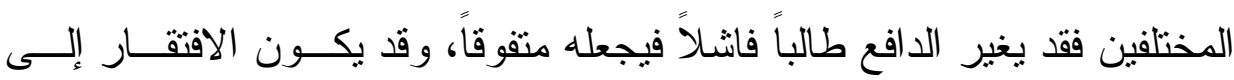

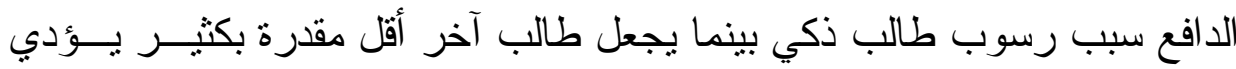
1961: 78)، D.C، (McClelland. هذا العمل بنجاح

ويؤكد ( مورجان morJan) هذه النتيجة بقوله : في الدر اســات العديــدة

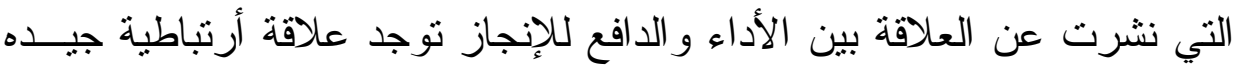

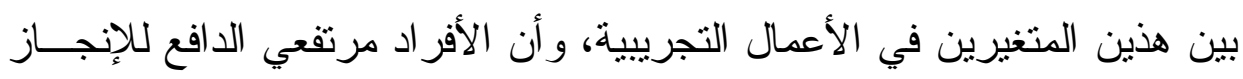

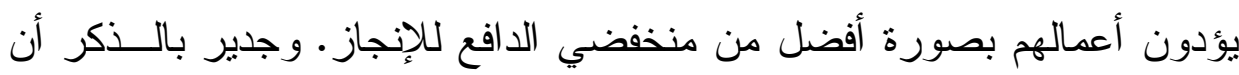

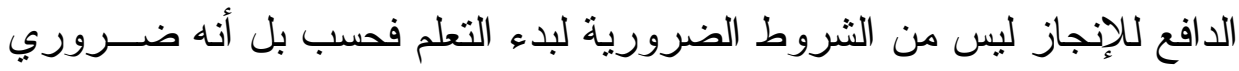

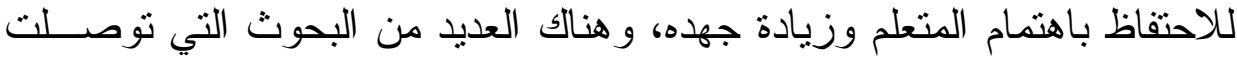

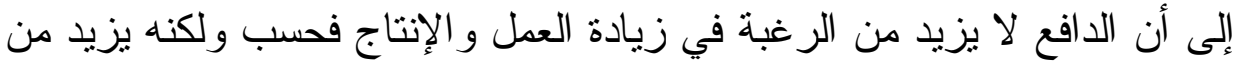

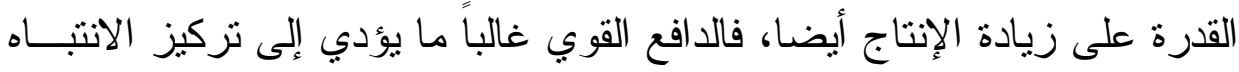

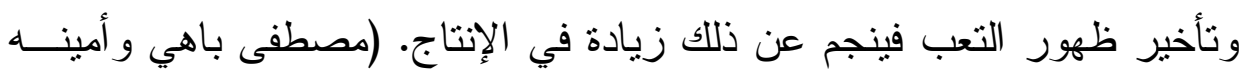

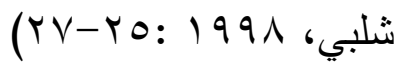




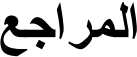

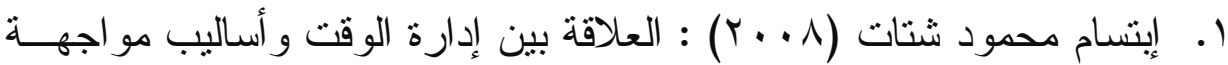
الضغوط ودافعية الإنجاز لدى طلاب المرحلة الثانوية ، رسالة دكتهور اه ، معهد در اسات الطفولة ، جامعة عين شمس . r. إير اهيم قشوش وطلعت منصور (9V9 (1):دافعية الإنجاز وقياسها : در اسات في علم النفس الدافعي ، المجلد الثاني ، مكتبة الأنجلو المصرية ، القاهرة . r. أصلان المساعيد (^ . . r) : الذكاء الإنفعالي وعلاقته بكل مــن التحـصيل الأكاديمي ودافع الإنجاز لدي طلبة الجامعة في ضوء بعض المتنغــر ات ،

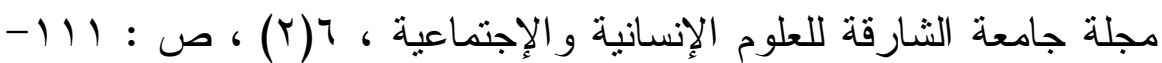
$.1 T V$ ع. أفر اح صالح صبر (11 (1) : سمات الثخصية و الدافعية و المناخ الأســري

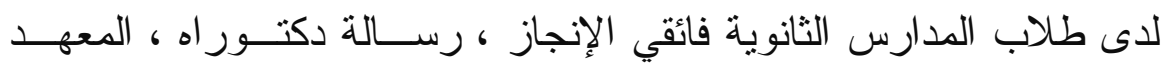
التزبوي جامعة القاهرة .

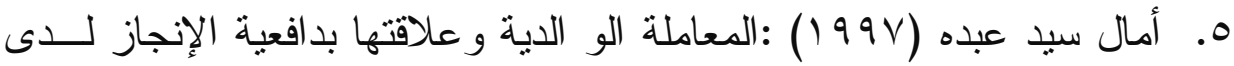

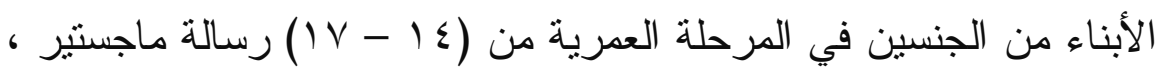

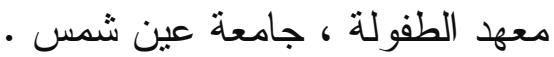
7. أمينة إبر اهيم شلبي (ب99 (19) : العلاقة بين اختلاف التقسير السببي لدافعيــة الإنجاز وتقدير الذات و الاتجاه نحو الدروس الخصوصية لدى طلبة المرحلة الثانوية ،رسالة ماجستير ، قسم علم النفس التزبوي ، كلية التزبية ، جامعة

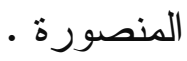




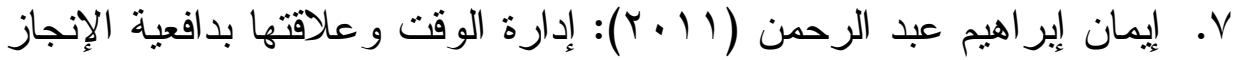

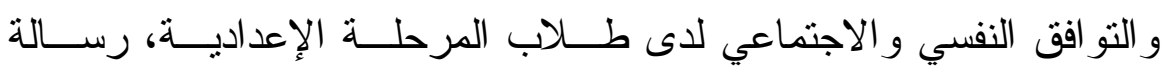
ماجستير • جامعة المنوفية.

1. حسن علي حسن (991)): سيكولوجية الإنجاز ،مكتبة النهضة المـصرية

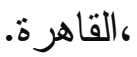

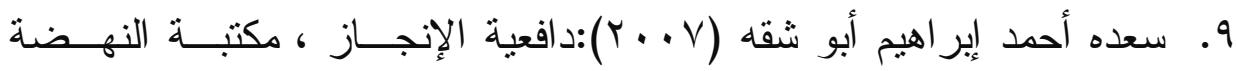
المصرية ، القاهرة. - ماهن

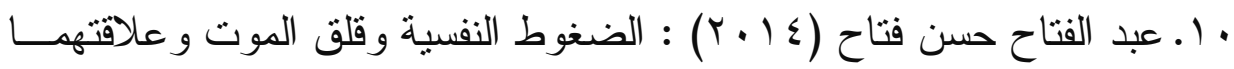

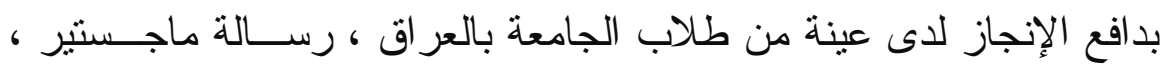

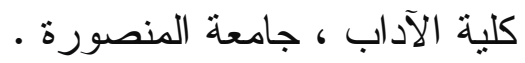

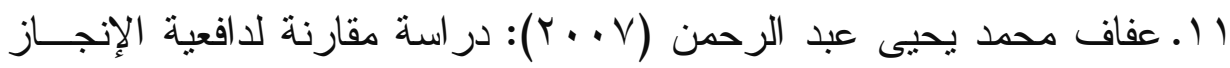

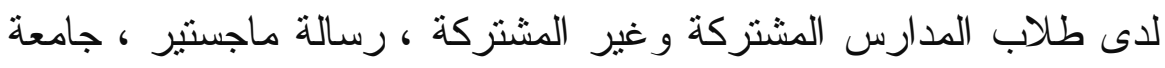
عين شمس ، معهد الطفولة .

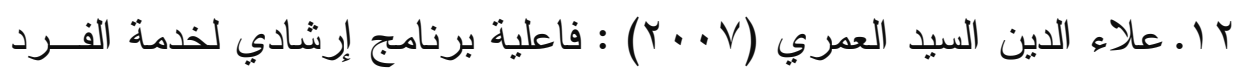

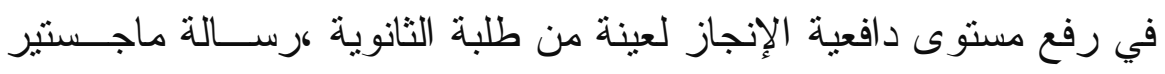
غير منشورة ، معهد الطفولة ، جامعة عين شمس .

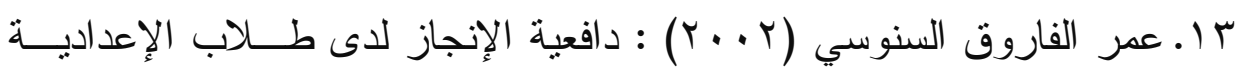
و الثانوية من الجنسين ، رسالة ماجستير ، معهد الدراسات العليا للطفولـــة ،

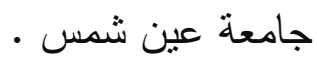

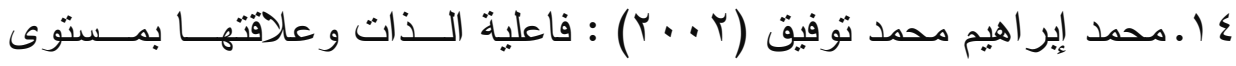

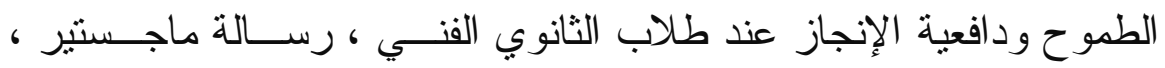
معهد البحوث التربوية ، جامعة القاهرة . 
1 ا. محمد عبد الغني عبد الحميد (990 1) : دراسة لدافعية الإنجاز مــن حيــث علاقتها ببعض متغير ات البيئة المدرسية ، رسالة ماجستير ، قسم الــصحة

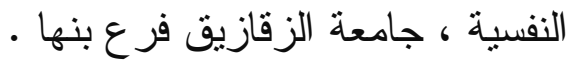

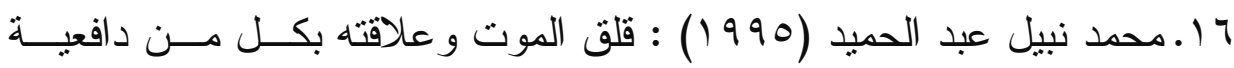
الإنجاز و الجنس ونوعية التعليم لدى عينة من طلاب الجامعة ، مجلة علــم

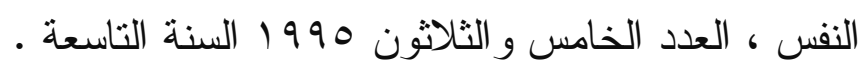

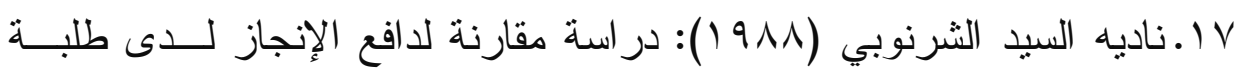
المرحلة الثانوية و علاقته بالتو اقق النفسي وبعض عو امل الثخصية ، رسالة دكتور اه غير منشورة ،كلية الدر اسات الإنسانية ، جامعة الأزهر .

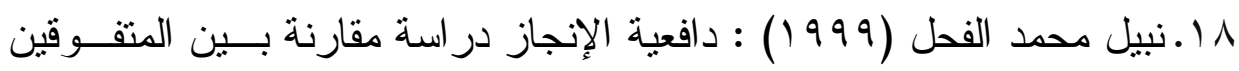
و العاديين من الجنسين في التحصيل الدر اسي بالصف الأول الثانوي ، مجلة

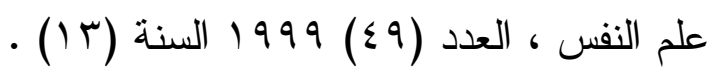

